\title{
Model of Sharia-based Tourism Industry Development in Banten Province
}

\author{
Tri Harjawati ${ }^{1}$, Andri Noor Ardiansyah ${ }^{2}$ \\ Faculty Lecturer Tarbiyah UIN Jakarta, Indonesia \\ Email : tri.harjawati@uinjkt.ac.id ${ }^{1}$, andri.noor@uinjkt.ac.id ${ }^{2}$
}

(Received: January-2021; Reviewed: February-2021; Accepted: March-2021;

Avalaible Online: march-2021; Published: March-2021)

(7) (5) This is an open access article distributed under the Creative Commons Attribution License EY NC CC-BY-NC-4.0 (2021 by author (https://creativecommons.org/licenses/by-nc/4.0/)

\begin{abstract}
This research is about the Sharia-Based Tourism Industry, the aim is to describe how the Sharia-based Tourism Industry Development Model is implemented in Banten Province. The method used is descriptive qualitative, with data collection techniques interview, observation, documentation, and literature study. The results showed that: 1) Banten Province has good tourism potential. This can be shown by the number of tourism objects (ODTW) as many as 526 objects which are divided into several categories, namely 84 natural attractions, 34 historical and cultural objects, 24 man-made tourism objects, 9 living culture objects and 48 art attractions. . 2) The Provincial Government's efforts towards a shariabased tourism industry, namely through fulfilling the provision of facilities towards sharia (such as toilets, prayer rooms), preparing WEB tourist destinations as tourism information material for the community, revitalizing the Sultanate of Banten because currently this place is synonymous with community icon about religious tourism in Banten 3). The sharia tourism development model in Banten Province is actually already in the preparation stage, but it has not yet been fully implemented towards sharia but has begun to be introduced through religious tourism. In the future the development model is through clear sharia regulations, after which a more intense introduction is made to the geographic contours in Banten Province, then a tourism zoning mapping is carried out according to the Provincial RJMD and PERDA No.6 of 2019 concerning the development master plan, after which the Provision is made. facilities towards sharia by paying attention to A3 (Amenitation, Attractions, and Accessibility), Provision of WEB Tourism Destinations as Promotions, Revitalizing several buildings that can be carried as sharia tourist destinations, Providing understanding, coaching and training to the community and several tourism industries both hospitality, transportation, food, transportation, tour gate, ekraf.
\end{abstract}

Keywords: Factors of interest in learning; learning discipline; student learning outcomes 


\section{INTRODUCTION}

The concept of sharia tourism in Indonesia has penetrated since 2012 and is increasingly being developed in the regions in 2015. Indonesia's achievements in the field of sharia tourism are not enough. In 2016, Indonesia again managed to wipe 12 out of 16 award categories in the World Halal event. Tourism Award 2016 in Abu Dhabi, United Arab Emirates. The concept of Sharia Tourism is a process of integrating Islamic values into all aspects of tourism activities (Husain et al., 2018; Papalapu et al., 2016; Said et al., 2017). The value of Islamic law as a belief and belief held by Muslims is a basic reference in building tourism activities. Sharia tourism considers the basic values of Muslims in its presentation ranging from accommodation, restaurants, to tourism activities that always refer to Islamic norms. The concept of Sharia tourism can also be interpreted as tourism activities based on worship and da'wah when Muslim tourists can travel and admire the results of Allah SWT's creation (tafakur alam) by continuing to carry out the obligatory prayer obligations five times a day and all of this is well facilitated and stay away from everything. which is prohibited by Him (Widagdyo, 2015).

Various efforts have been made to prepare tourism products with stakeholders, one of the ways is by introducing Sharia Tourism in Indonesia to the public and the international community through the holding of the Global Halal Forum with the theme Wonderful Indonesia as Moslem Friendly Destination on October 30, 2013 at JIExpo Kemayoran, Jakarta. The importance of developing the potential for sharia tourism was conveyed by Former President Susilo Bambang Yudhoyono at the launch of the Sharia Economic Movement (GRES) in the Monas cross area, November 17, 2013.He said that Indonesia has many reasons for developing the potential for sharia tourism, including reducing vulnerability between financial systems. with the real sector, thereby avoiding economic inflation, avoiding fluctuating financing, and can strengthen social security (Gumilar \& Sunarsi, 2020; Jaelani, 2017; Susanti et al., 2020).

The efforts made by the government at that time in developing sharia tourism were to prepare 13 (thirteen) provinces to become sharia tourist destinations, namely West Nusa Tenggara (NTB), Nangroe Aceh Darussalam, West Sumatra, Riau, Lampung, Banten, DKI Jakarta, Java. West, Central Java, Yogyakarta, East Java, South Sulawesi and Bali. However, of the 13 provinces declared ready, namely Jakarta, West Java, NTB, Yogyakarta and East Java (Yousaf \& Xiucheng, 2018).

Based on the data above, Banten Province is one of the sharia destinations that the government continues to develop. However, the implementation is not ready, this is a challenge for the regional government of Banten Province. Because, even though the area is relatively small, which is only 9,663 square kilometers or about 0.51 percent of the entire land area of Indonesia, Banten Province has many attractive tourist destinations which are currently partly developed. For example, Banten Province has a variety of tourism objects, ranging from marine tourism (Carita Beach, Tanjung Lesung, Umang Island, Anyer), ecotourism (Ujung Kulon, Gunung and Krakatau Island), cultural tourism (Baduy), religious tourism (Mesjin Agung) and tourism shopping (Cilegon, Serpong). However, it cannot be denied that some areas in Banten Province have not been touched, especially along the coast of Lebak Regency, Pandeglang Regency, Serang Regency and the beaches in Tangerang Regency (Rusby et al., 2020).

The aim of the Banten Provincial Government to improve and develop the tourism sector in the coming year seems to be right, because the province with a population of 12.4 million people is indeed rich in attractive tourist destinations that are not inferior to Bali, but unfortunately they have not been fully exploited. According to Rano Karno, he explained that there are two main problems in the development of the tourism sector in Banten, namely infrastructure and lack of tourism promotion. The infrastructure in question is poor road conditions, because good roads will cut the mileage and travel costs of tourists in choosing tourist destinations. Meanwhile, the tourism promotion carried out by the government does not 
resonate so that only some people will visit the destination. In fact, tourism development is very much benefited, not only hotel and restaurant owners or culinary de Based Tourism Industry Development Sharia Model (Pattullo, 2005).

In Banten Province lights, but also souvenir sellers to parking attendants feel these benefits. In Banten Province, district / city own revenue (PAD) from the tourism sector in 2017 is estimated to reach IDR 1 trillion or an increase of nearly 40 percent compared to the previous year. This increase comes from the culinary tourism sector which is dominated by the Tangerang region. "We have just played from culinary delights. In the future, if the road to the south is good where natural tourist destinations can be explored, we can imagine how much PAD could be donated, "said Ashok (Papatheodorou, 2004).

From the above statement, it can be seen that the determination of the Banten provincial government to make the tourism sector one of the mainstays of increasing PAD, especially since this province is rich in tourist destinations, as long as it is fixed and well organized, including facilities and infrastructure, namely roads that are smooth and without holes. Thus, the authors are interested in further researching the connection with the Sharia-based Tourism Industry with the title "Development of the Sharia-based Tourism Industry in Banten Province".

\section{METHOD}

This research uses qualitative methods, namely research or research that is descriptive in nature and tends to use analysis with an inductive approach. Data collection techniques through interviews with the Banten Province Tourism Industry Office, Observation, Survey, Documentation of tourist objects and literature studies. The data analysis technique used the Miles and Huberman analysis model through 3 stages, namely data reduction, data presentation, and conclusion drawing. Data collection is intended to obtain relevant and accurate materials. Triangulation in a study is important if researchers really want accurate data. Sugiyono (2011) states that triangulation is defined as a data collection technique that combines various existing data sources. For this reason, researchers use triangulation techniques in collecting different data to get data from the same source. The technique of collecting data by observation is used if the research is related to human behavior, work processes, natural symptoms and if the observed respondents are not too large. The implementation of data collection, observation is divided into two types, namely participant observation, which is involved in activities that are being researched or that are used as the source of the data being researched. Then, non-participant observation (non-participant) is that the researcher is not involved in activities only as an independent observer (Schensul et al., 1999; Vaismoradi et al., 2013).

\section{RESULT AND DISCUSSION}

Banten Province has many cultural heritage relics stretching from South Tangerang to Banten. These cultural heritage relics are in the form of historical sites that have been part of the cultural development of Banten long ago. According to the 2006 RIPPDA (Regional Tourism Development Master Plan) on the official website of the Banten Province Tourism and Culture Office, which is spread throughout the Banten Province. Consisting of 84 natural attractions, 34 historical and cultural attractions, 24 man-made tourism objects, 9 Living Culture attractions and 48 art attractions. According to data sources from the official website of the Banten Province Tourism and Culture Office, the number of Banten tourism objects (ODTW) based on 2012 data has been recorded as 526 objects which are divided into several categories. Namely, marina tours, historical tours, nature reserves, and other tourism objects (Indrajaya et al., 2019). 
Banten Province has 71 Tourist Attractions (ODTW) or (34.8\%) which are tourism areas that have developed both on a national and international scale. Meanwhile, around 100 tourism objects or $(49.0 \%)$ are tourism objects that have the potential to be developed. One of the most interesting is the Old Islamic Age Urban Heritage Area, namely the Old Banten Cultural Heritage Tourism Area. This area consists of many cultural heritages which will be detailed in the table below.

The following is a recap of data on tourist visits both from within the country and from abroad, namely:

Table 1. Data on Tourist Visits to Pandeglang Regency in 2017

\begin{tabular}{llrrl}
\hline \multirow{2}{*}{ NO } & \multicolumn{1}{c}{ Month } & \multicolumn{2}{c}{ TRAVELER } & TOTAL \\
\cline { 3 - 4 } & & WISNUS & WISMAN & \\
\hline $\mathbf{1}$ & January & 372,580 & 135 & 372,715 \\
$\mathbf{2}$ & February & 281,017 & 139 & 281,156 \\
$\mathbf{3}$ & March & 234,970 & 299 & 235,269 \\
$\mathbf{4}$ & April & 241,792 & 180 & 241,972 \\
$\mathbf{5}$ & May & 222,445 & 99 & 222,544 \\
$\mathbf{6}$ & June & 893,948 & 178 & 894,126 \\
$\mathbf{7}$ & July & 537,876 & 155 & 538,031 \\
$\mathbf{8}$ & August & 258,673 & 194 & 258,867 \\
$\mathbf{9}$ & September & 257,679 & 297 & 238,833 \\
$\mathbf{1 0}$ & October & 238,629 & 204 & 238,833 \\
$\mathbf{1 1}$ & November & 102,463 & 53 & 102,516 \\
$\mathbf{1 2}$ & December & 188,955 & 41 & 188,996 \\
\hline TOTAL & & $3,831,027$ & 1,974 & $3,833,001$ \\
\hline
\end{tabular}

\section{Source : Tourism Office of Pandeglang Regency, January 2018}

The dominance of the number of tourists who come in the Banten region is due to the existence of religious tourism places which causes many domestic tourists to come to visit these places for pilgrimages. Banten is located in the western tip of the island of Java and has a very strategic position and has enormous economic potential both locally, regionally, nationally, even internationally. Facilitation of the movement of goods and passengers from and to national, regional and local activity centers in Banten Province is very important in an effort to support economic development in the Banten Province. In general, the transportation sector can be categorized into 3 parts, namely land transportation, sea transportation and air transportation. These three parts have a very important role in building the economy in Banten Province (Jaelani et al., 2016).

The tourism sector is one of the productive contributions which until now must be developed as a source of income. Natural characteristics and values of community life are very possible to be developed as tourism potential. It is undeniable that tourism is the largest business activity in the world today and has grown rapidly. With the success of finding a means of transportation that is faster and has a greater load capacity, it has brought tourist areas that were previously considered far closer. The increase in travel has prompted a need for the provision of tourism facilities (Zapata et al., 2011) (Zapata et al., 2011).

Tourism Sector Regional Spatial Planning:

- Development work areas I are Tangerang City and Tangerang Regency with the main activities being industry, trade, services and education. The strategic direction and WKP are the construction of an integrated transportation network for the city of Tangerang, the development of the Argobisnis terminal, facilitation of the construction of the serpongbalaraja road and the provision of housing for the slum area. 
- Development work areas II, namely Cilegon City and Serang Regency. Its main activities are agricultural and mining tourism, industry, forestry and education. The WKP's strategic direction is the development of the integrated terminal of Merak, the southern ring road of Cilegon, the construction of the Kubang Sari port, the construction of the Cikande interchange road, the facilitation of access to the center of Serang city government, the development of agropiolitan development of the Bojonegoro special economic area.

- Development working areas III, namely Pandeglang and Lebak Regencies with the main activities of tourism, agriculture, mining, forestry and education. The WKP's strategic direction is the handling of rural areas underdeveloped electricity, rehabilitation and conservation of root essence protected areas, agripolitan development.

The authority of the government in a rule of law that uses policies as a legality principle in its constitution as stated in article 1 paragraph 3 of the 1945 Constitution, the third amendment implies that government administration must be based on law and provide guarantees for people's rights. Regional development planning includes all development sectors whose citizenship has been submitted to the regions and one of them is the tourism sector. In the preparation of tourism, the local government must be able to formulate a strategic plan that is systematic, comprehensive, and aspirational in order to realize regional development in accordance with its vision and mission. Tourism development is a public policy, because tourism is the result of the government's choice and the right of the government to develop and control this development. Policy can be said to be successful if human resources, intuition, and the organization reengineer (Enright \& Roberts, 2001).

Law No. 10 of 2009 concerning tourism regulates the opportunities for utilization and development of tourism resources which are the responsibility of all related parties, especially for local governments that own and manage all the assets that their regions have. To support the regional development of Banten Province, the local government made a policy in the form of a Tourism Development Master Plan (RIPPDA) by issuing PERDA No.9 of 2005 concerning the Tourism Development Master Plan (RIPPDA). Banten province is expected to encourage the regional tourism sector to make a positive contribution, but until now Banten Province has not been able to carry out as expected, besides that the region also has limitations such as in infrastructure and accessibility.

Tourism policy is generally seen as part of economic policy, economic policy is related to the structure and economic growth which is usually manifested in tourism development. One of the ways the government policy is to provide financial incentives to attract incoming investment. These incentives can be in the form of grants or loans made for projects with certain criteria. There are 5 factors of public involvement in tourism, namely: 1) Coordination, 2) Planning, 3) Legislation, 4) Entrepreneurship regulations, 5) Entrepreneurial stimulation (Hall \& Jenkins, 1995).

The government's commitment has an important role in the successful achievement of development in the tourism sector, the weak degree of commitment of the government of a country in tourism development affects the success rate of tourism development and a strong government commitment that akasehin is able to mobilize the resources it has so that tourism development can be accelerated and optimized. Tourism business activities are multisuctoral, involving various sectors such as transportation, telecommunications, public works, health, defense and security, the condition of society, industry, government and so on. This requires the role of the government to carry out mobilization that is able to drive tourism interests from national to local levels. Commitment to synergize all sectors so that they do not overlap is very important (Ramayah et al., 2011).

Tourism development by providing opportunities for local entrepreneurs to invest in various tourism industries is a policy that must be carried out by the government, this policy 
will show the sensitivity of the effects of tourism development on the economy, environment and society. The government implements policy standards for tourism, such as building heights not exceeding coconut trees or 15 meters, the ratio of land or buildings to green open spaces, structures and designs of building materials according to local characters, utilization of local products, and other requirements related to the optimization of local products. Sustainable development is a conscious and planned effort that puts environmental, social and economic aspects into a development strategy to ensure environmental integrity as well as safety, capability, welfare, and quality of life for present and future generations. At the national level, Law no. 32 of 2009 concerning the protection and management of the environment in its consideration of securing national economic development based on the principles of sustainable and environmentally sound development, while in the tourism sector Law No.10 of 2007 on tourism mandates an integral part of national development to be carried out in a systematic, planned, integrated, sustainable manner, and are responsible while providing protection for religious values (Yang et al., 2008).

The following are the results of research observations, namely:

Table 2. Observation Results

\begin{tabular}{|c|c|c|c|c|c|}
\hline \multirow[t]{2}{*}{ No } & \multirow[t]{2}{*}{ Object Name } & \multicolumn{3}{|c|}{ The Observer } & \multirow[t]{2}{*}{ Information } \\
\hline & & $\begin{array}{c}\text { Coordinate } \\
\text { Location }\end{array}$ & Aminities & Condition & \\
\hline 1 & $\begin{array}{l}\text { Banten Grand } \\
\text { Mosque }\end{array}$ & & Complete & Good & $\begin{array}{l}\text { Complete facilities } \\
\text { include spacious places } \\
\text { of worship, ablution } \\
\text { places, toilets, storage of } \\
\text { goods. }\end{array}$ \\
\hline 2 & $\begin{array}{l}\text { Minaret of the } \\
\text { Mosque Agung }\end{array}$ & $\begin{array}{l}06^{0} 02.175 \\
\quad-106^{0} \\
09.254\end{array}$ & Complete & Good & $\begin{array}{l}\text { It is in good condition } \\
\text { because it has been } \\
\text { completed in the } \\
\text { renovation stage of the } \\
\text { tiled courtyard }\end{array}$ \\
\hline 3 & $\begin{array}{l}\text { Tomb of Sultan } \\
\text { Maulana Hasanudin } \\
\text { Banten }\end{array}$ & $\begin{array}{l}06^{0} 02.182 \\
-106^{0} \\
09.276\end{array}$ & Complete & Good & $\begin{array}{l}\text { Complete facilities cover } \\
\text { a place of pilgrimage } \\
\text { which is quite spacious } \\
\text { and equipped with a fan, } \\
\text { other facilities and } \\
\text { infrastructure are hung in } \\
\text { the area of the Grand } \\
\text { Mosque. The condition } \\
\text { is also good, neatly } \\
\text { arranged between the } \\
\text { graves and other graves }\end{array}$ \\
\hline 4 & $\begin{array}{l}\text { Al Quraniyah } \\
\text { Islamic boarding } \\
\text { school }\end{array}$ & $\begin{array}{l}06^{0} 02.317 \\
\quad-106^{0} \\
09.276\end{array}$ & Complete & Good & $\begin{array}{l}\text { Good condition with } \\
\text { complete facilities like } \\
\text { other Islamic boarding } \\
\text { schools }\end{array}$ \\
\hline 5 & $\begin{array}{l}\text { Al Mukaromah } \\
\text { Mosque } \\
\text { Acculturation }\end{array}$ & $\begin{array}{l}06^{0} 02.225 \\
-160^{0} \\
09.804\end{array}$ & Complete & $\begin{array}{l}\text { Pretty } \\
\text { good }\end{array}$ & $\begin{array}{l}\text { Fairly good conditions, } \\
\text { lack of mosque parking } \\
\text { space }\end{array}$ \\
\hline 6 & Keraton Surosowan & $\begin{array}{l}06^{0} 02.598 \\
\quad-106^{0}\end{array}$ & - & Not good & $\begin{array}{l}\text { The condition of the } \\
\text { place is a little dirty due }\end{array}$ \\
\hline
\end{tabular}




\begin{tabular}{|c|c|c|c|c|c|}
\hline No & Object Name & & The Obse & & Information \\
\hline & & 09.475 & & & $\begin{array}{l}\text { to the absence of } \\
\text { temporary garbage } \\
\text { storage places }\end{array}$ \\
\hline 7 & Keraton kaibon & $\begin{array}{l}06^{0} 02.257 \\
-106^{0} \\
09.311\end{array}$ & Complete & $\begin{array}{l}\text { Pretty } \\
\text { good }\end{array}$ & Still under renovation \\
\hline 8 & Benteng speelwijk & $\begin{array}{c}06^{0} 02.243 \\
-106^{0} \\
09.166\end{array}$ & Complete & $\begin{array}{l}\text { Pretty } \\
\text { good }\end{array}$ & Still under renovation \\
\hline 9 & $\begin{array}{l}\text { Vihara } \\
\text { avalokistevara }\end{array}$ & $\begin{array}{l}06^{0} 01.853 \\
-106 \\
08.979\end{array}$ & Complete & Good & $\begin{array}{l}\text { Complete facilities } \\
\text { include a place of } \\
\text { worship, a large parking } \\
\text { area, toilets, a place to } \\
\text { eat and a garden }\end{array}$ \\
\hline 10 & $\begin{array}{l}\text { Eat the prince who } \\
\text { watches over the } \\
\text { oceans }\end{array}$ & $\begin{array}{l}06^{0} 04.720 \\
\quad-106^{0} \\
26.503\end{array}$ & Complete & Good & $\begin{array}{l}\text { Complete facilities } \\
\text { include a place of } \\
\text { pilgrimage which is quite } \\
\text { spacious, comfortable } \\
\text { and clean }\end{array}$ \\
\hline 11 & Lake tasikardi & $\begin{array}{l}06^{0} 04.458 \\
-106^{0} \\
09.430\end{array}$ & Complete & $\begin{array}{l}\text { Pretty } \\
\text { good }\end{array}$ & $\begin{array}{l}\text { Complete facilities } \\
\text { include a prayer room, } \\
\text { toilets, huts, fishing } \\
\text { grounds, boat rental, } \\
\text { ample parking space. } \\
\text { The condition is quite } \\
\text { good but seems like } \\
\text { there is a lack of } \\
\text { maintenance }\end{array}$ \\
\hline 12 & Museum of change & $\begin{array}{l}06^{0} 02.189 \\
-106^{0} \\
09.345\end{array}$ & Complete & Good & $\begin{array}{l}\text { Complete facilities } \\
\text { include a large parking } \\
\text { area, toilets, guard posts. }\end{array}$ \\
\hline
\end{tabular}

Source : the results of data processing.

In this study, the authors interviewed 4 respondents from the Banten Province Tourism Office, namely Mr. Wadiyo (Secretary of the Tourism Office), Mr. Aldofina Nopelis Katemba (Head of Government Tourism Office Marketing), Mr. Undra Bayu Aji (Head of the Tourism Destinations Section, Tourism Office Development Division), Mrs. Hj. Linda Rohyati (Head of Tourism and Tourism Human Resources), and Ms. Tunul Lasmiatin (Head of Tourism Industry Standardization). From the results of the interview, it was found that:

Procedurally Banten Province has a policy direction towards sharia tourism, but to become sharia at this time it is not yet because there must be an agreement with all parties so that there is involvement between the community and the government. Is it related to the tour guide, travel, hotels, and so on which includes the participation of all levels of society. However, even though it is not yet sharia, tourism in Banten Province has led to religious tourism such as in Old Banten which has become an icon for the general public. The government has prepared infrastructure towards sharia in every tourist destination, such as a prayer room and ablution place but not yet for the sharia system. In Banten Province, there are approximately 1,016 destinations covering natural and cultural tourism, including artificial 
tourism. Artificial tourism here such as waterboom, maes (exhibition) including shopping tours (Samori et al., 2016).

So far, the way the Tourism Office promotes tourism destinations in Banten Province is through maps, pocket maps, smart books, off-event calendars, events, promotional news in newspapers, TV, web, and local radio..

The obstacles in developing tourist destinations in Banten Province in general are funds, Money to Function. As long as there is a budget, programs will be carried out. The steps taken by the tourism office to minimize these obstacles are by applying for funds to the top so that the program can be implemented. However, the obstacles for each division or section in Government Tourism Office, namely the obstacles felt by the development section in Government Tourism Office, namely that there are so many, one of which is infrastructure, such as roads, bridges by paying attention to the mapping related to 3A (Amenities, Accessibility, and Attractions). The steps taken by Government Tourism Office to minimize the first obstacles are that there must be cooperation, communication, and coordination with other fields. We give the designs and concepts to them and those who work on them or execute them. Furthermore, we will provide socialization to the community which aims to make people ready that tourist destinations will be built or developed in their area, because it is useless if we organize and build them if the community is not ready in their area to become a tourist destination, they can not be moved to build tourism, because tourism cannot run alone, so it must be connected by all existing elements, one of which is community empowerment (Khazai et al., 2018).

Another obstacle is that the Tourism Human Resources Development Center in Banten Province does not yet exist, because so far the development has been in Jakarta. If the deputy of the Tourism Human Resources development is there, the name is the Tourism Institution. For example, there is one such as the Tirta Tourism Rescue Agency, their job is here, they save beach visitors, they save visitors who are on vacation. If in Banten the name is the Tirta Tourism Rescue Agency, it still doesn't have a building, but it does exist, even though the building is still contracted, it is already around Carita. Train from starting a guide to escorting visitors, they are able to master multilingualism. There is one name, Pak Tomi, he is able to master five languages. There is no human resource development manager specifically but there is an instruction from the provincial ministry that is delivered starting from understanding, revitalization and others based on regulations.

The obstacle faced by the HR department in developing tourism human resources in Banten Province is that the community does not respond quickly when they know that we will provide material about tourism, usually those who respond well are millennials, for those who are above my age they will catch it slowly. But of the eight districts / cities that I have explored, the average number of mothers who want to know a lot about it through technology. If we look at the origin of this, we will prepare sharia-based destinations, but the form of support to get there is not as easy as people imagine. Because there must be legal regulations that are binding and overarching, when there must be a coalition that determines, but we have explored this because Banten is famous for its religious tourism. The most important thing is that at this time we are jointly fulfilling the wishes of the population as well as a suggestion from the minister of tourism that Banten has no history or record in this world except for its tourism objects. Measuring from other tourist objects we are only at a moderate level. Because we also follow the times, that there are the best tourism objects, and the bad ones we can still make good. But if religious tourism in Banten is chosen one of them. And famous and famous because many of our heroes come from Banten. So our concern for religious tourism will develop, but has society accepted it? this is what we need to focus on because this is what we are going to aim for. If we focus on sharia tourism, we haven't focused there yet because our concern is natural tourism that has grown, has developed, then has gone viral. Well, this is one of them we have classified into 
special categories, but have not yet focused on sharia tourism. However, if there is a direction in that direction (sharia), God willing, there is because our potential is religious tourism (Burns \& Howard, 2003).

Another obstacle that causes sharia-based tourism to be unable to be implemented in Banten is the religious tourism policy which still has to be reviewed, socialization to the community, cultural differences that exist in Banten and Serang communities. The city of Cilegon is culturally free, Lebak and Pandeglang are both thick with Islamic culture, Serang Regency and Serang City are a little separated from the impression of Islam. Tangerang and South Tangerang are not said to be unsafe. So the characteristics of districts / cities in Banten are very different in order to lead to sharia tourism, so it cannot be easily taken, where to take it first, whether it starts with a thick religious one to a very conventional one. So, of the eight districts / cities that already exist, in fact the districts of Pandeglang, Lebak and Kota Serang Kalu Cilegon are very modern. For Tangerang Raya the ratio is 4: 3, but it will definitely go there (sharia-based tourism).

There is no policy for the development of sharia tourism, but the provision of facilities towards sharia is sufficient. This is because the sharia label is very heavy, yes sharia regulations must be clear because its implementation will involve community components, such as online motorcycle taxis, the management must be sharia, all aspects of beach life, for example sharia, are also afraid it will be troublesome for all parties.

There is no policy for the development of sharia tourism, but the provision of facilities towards sharia is sufficient. This is because the sharia label is very heavy, yes sharia regulations must be clear because its implementation will involve community components, such as online motorcycle taxis, the management must be sharia, all aspects of beach life, for example, must be sharia, also afraid that it will be troublesome for all parties. Sharia tourism can be carried out in Banten Province, which is to provide variants that there are tourist attractions based on sharia and general. Because if tourism cannot prioritize one culture or one religion, we are multifunctional here. So for the time being in particular, Banten has not focused on sharia-based tourist points, but with the development focused on the Sultanate of Banten (Tanara Sultanate) and others, it will definitely become a focal point for the development of sharia tourism. The hope is that they are ready to accept, because there are variant parts that we offer. The religious tourism in question, for example, is a fanatical Muslim when women do not want to be next to someone who is not their mahrom or they do not want to open their genitals carelessly. There must be a class selected, the mapping so far is not yet (Smith, 2009).

The task of developing tourist destinations in Government Tourism Office is divided into 3:1. development of tourist attractions, 2. Management of strategic areas, 3. Community empowerment, to increase the development of tourist destinations. So far, the way the tourism office has developed tourist destinations in the province is through the geographical contours of Banten Province such as mountains, caves, waterfalls, rivers and beaches. After that, zoning several areas into the provincial tourism strategic zone and tourism development zone based on the spatial pattern as stated in the Provincial Medium-Term Development Plan (RJMD) and PERDA No.6 of 2019 regarding the master plan for the development of tourism destinations in Banten Province. or area. After that, determine which area the focus point is so that we have a well-structured and well-planned development pattern.

What must be considered by the Tourism Office, especially the ecraf section, if shariabased tourism is running in Banten Province, is following the trend towards the image that is being carried out, namely religious tourism. Banten is currently the center of religious tourism, this was triggered in the framework of making an Islamic center through the Restoration of the Tanara Sultanate in Serang. The Banten Province Tourism Office through the HR department has the task of HR and Tourism Development in the form of providing understanding, coaching 
and training based on tourism. So the goal is to make people around tourist objects have quality human resources, especially tourism. The development of tourism human resources in Banten Province is more concerned with cultural aspects. Due to the increase in data, understanding, and knowledge, in our opinion, the government has reached the stage of improvement because we teach almost all villages that have tourist objects to be able to relocate tours that are made to invite other people to know the tourism in their area. So it means that it has gone to tourism and it is improving (Baum, 2015).

The community is very enthusiastic when there is a seminar or training. This target has already been exceeded, but we are not exceeding enough. But it is not worthy to be proud, meaning that we are already regulated by the Regional Medium Term Development Plan (RPJMD), we have done it because two years ago we had targeted around 200 or 400 people trained by us but it turned out that even though our quota was booming we had to seek support and support so we submit the request to the ministry of tourism in this case we say the central government. The one-year target is 300 people, we have exceeded the limit in 2017 we have trained nearly 900 people who are eager to know about tourism. Increase in the following year, our target is 300 people and those who follow are more than 1800 people.

For tourism development models, both public and sharia tourism, of course, it must be related to A3 (Amenitation, Attractions, and Accessibility). The amenities here must have toilets, landmark arrangement, roads and others. If the attractions are like culture, nature and others like a country above the clouds, if there is a sunrise in the morning it is part of destination development. For promotion there are promotion and marketing fields. For manual marketing, through festival events and social media promotions such as Genpi (Generasi Pesona Indonesia), for example, Land Above Clouds, dp promotion through social media. So that every Saturday-Sunday it is crowded because of social media, it is part of the promotion, including advertising such as billboards, banners, and others. Then the HR sector will be aware of the enchantment of the environment that is instilled by the community, how the tourism industry players are in the HR field. One more thing in the field of destination development, its task is to standardize tourism destinations in order to increase, such as hotels, travel, and so on, including the creative economy being developed in the field of tourism destinations (Adha et al., 2019).

Sharia tourism development model in Banten Province in the future, depending on the destination.For example pilgrimage, starting from food vendors, hotels, and infrastructure must be based on sharia, how are the pathways between men and women separated, and the management of tourist destinations must be based on sharia or Islamic law. And for sharia tourism, we will highlight Islamic cultural events that still exist in the midst of the Banten community. Our hope is that sharia or religious tourism in Banten will be known to many people, not only in Indonesia but abroad. What we feel is related to the development of halal tourist destinations, we are happy that many people have started to come and know about sharia or religious tourism in Banten Province and I as the head of the Development of Tourism Destinations are very happy that many people come for pilgrimages, especially remembering if the majority of the people of Banten and Indonesia themselves are Muslims. This will be a plus or attraction to attract many foreign tourists who come to visit the Banten area.

Banten Province has 526 tourism objects (ODTW) which are divided into several categories, namely marina tourism, historical tourism, nature reserves, and other tourism objects with details of 84 natural tourism objects, 34 historical and cultural tourism objects, 24 tourism objects. artificial, 9 Living Culture attractions and 48 art attractions. One of the most interesting tourist objects is the most complete Old Islamic Age Urban Heritage Area, namely the Old Banten Cultural Heritage Tourism Area. This area consists of many cultural heritages, namely the Old Banten Grand Mosque, the Banten Sultanate Grand Mosque Square, the Banten Grand Mosque Tower, Tiyamah, the Surosoan Palace, the Chain Bridge, the Old Banten 
Archaeological Site Museum, the Spelwijk Fort, the Chain Bridge, the Kherkof, the Chinatown Mosque., Avalokitesvara Temple, Pengindelan Abang, Tasikardi, Karang Antu, Kaibon Palace, Kenari Mosque, Maulana Yusuf Cemetery.

The potential above turns out to provide its own magnet for both domestic and foreign tourists, this is evidenced by the number of tourists visiting Banten province which has increased every year, this can be seen in the number of tourists staying at Banten hotels. The dominance of the number of tourists who come in the Banten area are domestic tourists with the intention of religious tourism visiting places for pilgrimages and exploring the thick Islamic history in Banten such as the Banten Grand Mosque, the Surosowan Palace, the Kaibon Palace, the Speelwijk Fortress, the Old Banten Archaeological Museum, and still many more places of religious tourism.

Although the implementation of sharia tourism in Banten Province has not been implemented, the efforts of the provincial government to become a sharia-based tourism industry, namely through fulfilling the provision of facilities towards sharia, preparing WEB for tourist destinations as tourism information material for the community, including in the future the choice of sharia-based tourist destinations. revitalization of the Sultanate of Banten because currently the place is synonymous with the icon of the community about religious tourism in Banten and in the future it will be made into an Islamic center, providing variants of shariabased and general tourism objects, then providing understanding, coaching and training based on tourism to the surrounding community The community around the tourist attraction knows about tourism in the area so that Banten Province has quality human resources, especially tourism (Goodwin, 2002).

The steps taken in general by the Banten Province Tourism Office are knowing carefully the geographical contours of Banten Province such as mountains, caves, waterfalls, rivers and beaches. After that, zoning several areas into the Provincial Tourism strategic zone and the tourism development zone based on the spatial pattern according to the Provincial Medium-term Development Plan (RJMD) and PERDA No.6 of 2019 regarding the master plan for developing tourism destinations in Banten Province. or area. After that, determine which area the focus point is in order to have a well-structured and well-planned development pattern (Aly et al., 2019).

Banten Province is established based on Law No.23 of 2000 stretching from the edge of the Sunda Strait on the west side of the island of Java, the Java Sea and the Indian Ocean. With that the location of the province of Banten is very strategic, because it has potential tourism objects and destinations including the potential for marine tourism, Banten also has the potential for religious tourism and historical tourism. However, based on the results of the interview, information was obtained that the concept of developing sharia tourism in Banten province is still in discourse but currently the preparation and development stage of Islamic tourism is starting. Even though there is no regulation, but indirectly the implementation of Islamic tourism has been implemented, namely more on religious tourism. This is in accordance with the implementation of Regional Regulation No.9 of 2005 concerning the Regional Tourism Development Master Plan (RIPPDA) of Banten Province, namely historical and ancient relics, including historical places, buildings and ancient mosques and socio-cultural and religious life, among others. includes customs, religion and kinship.

In the future, the sharia tourism development model in Banten Province will be developed depending on the destination by paying attention to A3 (Amenitation, Attractions, and Accessibility). For example a pilgrimage, starting from food vendors, hotels, and infrastructure must be based on sharia, how are the pathways between men and women separated, and also the management of tourist destinations must be based on sharia or Islamic law. And for sharia tourism, we will highlight Islamic cultural events that still exist in the midst of the Banten 
community. In addition, the HR sector will be aware of the environmental charm instilled by the community related to the culture in the area, in the field of destination development, standardizing tourism destinations with Islamic nuances such as hotels, travel, and so on, including the creative economy developed in the field of tourism destinations (Russo \& Richards, 2016).

This is in accordance with what was said by Haidar, Andi, Karimatul, Ikhwanul, and Adityawarman who stated that sharia tourism can run if it can meet the requirements including Sharia tourism facilities must pay attention to the guarantee of halal food availability, not neglect prayer equipment, friendly and friendly tour gates. , Services provided follow the applicable halal standards, as well as lodging or drinking places.

\section{CONCLUSION}

1. Banten Province has 526 tourism objects (ODTW) which are divided into several categories, namely marina tourism, historical tourism, nature reserves, and other tourism objects with details of 84 natural tourism objects, 34 historical and cultural tourism objects, 24 tourism objects. artificial, 9 Living Culture attractions and 48 art attractions. One of the most interesting tourist objects is the most complete Old Islamic Age Urban Heritage Area, namely the Old Banten Cultural Heritage Tourism Area.

2. The Provincial Government's efforts towards a sharia-based tourism industry include fulfilling the provision of facilities towards sharia (such as toilets, prayer rooms), preparing WEB tourist destinations as tourism information material for the community, revitalizing the Sultanate of Banten because currently the place is synonymous with community icons. about religious tourism in Banten and in the future it will be made into an Islamic center, providing variants of tourist objects based on sharia and general, then providing understanding, coaching, and training based on tourism to the surrounding community so that people around tourist objects know the tourism in their area so that Banten Province has qualified human resources, especially tourism.

3. The sharia tourism development model in Banten Province is actually already in the preparation stage, but it has not yet been fully implemented towards sharia but has begun to be introduced through religious tourism. In the future, the development model is through clear sharia regulations, after which there is a more intense introduction to the geographic contours in Banten Province, then a tourism zoning mapping is carried out according to the Provincial RJMD and PERDA No.6 of 2019 concerning the development master plan, after which the Provision is made. facilities towards sharia by paying attention to A3 (Amenitation, Attractions, and Accessibility), Provision of WEB Tourism Destinations as Promotions, Revitalizing several buildings that can be carried as sharia tourist destinations, Providing understanding, coaching and training to the community and several tourism industries both hospitality, transportation, food, transportation, tour gate, ekraf. Of course, religious tourism that can be highlighted is in the form of Islamic cultural events that still exist in the midst of the Banten community. 


\section{REFERENCES}

Adha, M. M., Budimansyah, D., Kartadinata, S., \& Sundawa, D. (2019). Emerging volunteerism for Indonesian millennial generation: Volunteer participation and responsibility. Journal of Human Behavior in the Social Environment, 29(4), 467-483.

Aly, M. N., Yuliawan, R., Noviyanti, U. D. E., Firdaus, A. A., \& Prasetyo, A. (2019). Public policy and rural tourism development in East Java Province, Indonesia. African Journal of Hospitality, Tourism and Leisure, 1-8.

Baum, T. (2015). Human resources in tourism: Still waiting for change? - A 2015 reprise. Tourism Management, 50, 204-212. https://doi.org/https://doi.org/10.1016/j.tourman.2015.02.001

Burns, G. L., \& Howard, P. (2003). When wildlife tourism goes wrong: a case study of stakeholder and management issues regarding Dingoes on Fraser Island, Australia. Tourism Management, 24(6), 699-712.

Enright, M. J., \& Roberts, B. H. (2001). Regional clustering in Australia. Australian Journal of Management, 26(1_suppl), 65-85.

Goodwin, H. (2002). Local community involvement in tourism around national parks: opportunities and constraints. Current Issues in Tourism, 5(3-4), 338-360.

Gumilar, I., \& Sunarsi, D. (2020). Comparison of financial performance in banking with high car and low car (Study of banks approved in the kompas 100 index for the period 20132017). International Journal of Psychosocial Rehabilitation, 24(7).

Hall, C. M., \& Jenkins, J. M. (1995). Tourism and public policy. A Companion to Tourism, 1(1), 523-540.

Husain, T., Akib, H., Gani, H. A., \& Guntur, M. (2018). Collaboration of actor in formulation of development program tourism destination in West Halmahera Regency. (Study In Tuada and Bobanehena Village, Jailolo District) - Indonesia. Espacios, 39(44).

Indrajaya, T., Cahyandito, M. F., Wiweka, K., \& Adnyana, P. P. (2019). The development of creative industry strategies as a tourist attraction in Banten Province, Indonesia. Journal of Economics, Management and Trade, 1-10.

Jaelani, A. (2017). Halal tourism industry in Indonesia: Potential and prospects.

Jaelani, A., Setyawan, E., \& Hasyim, N. (2016). Religious heritage tourism and creative economy in Cirebon: The diversity of religious, cultures and culinary. Journal of Social and Administrative Sciences, 3(1).

Khazai, B., Mahdavian, F., \& Platt, S. (2018). Tourism Recovery Scorecard (TOURS)Benchmarking and monitoring progress on disaster recovery in tourism destinations. International Journal of Disaster Risk Reduction, 27, 75-84.

Papalapu, D. M., Nawawi, J., Tahir, H., \& Akib, H. (2016). The role of the department of social in empowering the street children in Makassar. International Journal of Economic Research, 13(1).

Papatheodorou, A. (2004). Exploring the evolution of tourism resorts. Annals of Tourism Research, 31(1), 219-237.

Pattullo, P. (2005). Last resorts: The cost of tourism in the Caribbean. NYU Press. 
Ramayah, T., Lee, J. W. C., \& In, J. B. C. (2011). Network collaboration and performance in the tourism sector. Service Business, 5(4), 411-428.

Rusby, Z., Arif, M., No, J. K. N., \& Marpoyan, P. (2020). Development of Sharia Tourism in Riau Province Indonesia. African Journal of Hospitality, Tourism and Leisure, 8 (5).

Russo, A. P., \& Richards, G. (2016). Reinventing the local in tourism: Producing, consuming and negotiating place. Channel View Publications.

Said, F., Salam, R., Akib, H., \& Baharuddin, A. (2017). An Analysis of Tourism Visit Trend. 149(Icest), 34-36.

Samori, Z., Salleh, N. Z. M., \& Khalid, M. M. (2016). Current trends on Halal tourism: Cases on selected Asian countries. Tourism Management Perspectives, 19, 131-136.

Schensul, S. L., Schensul, J. J., \& LeCompte, M. D. (1999). Essential ethnographic methods: Observations, interviews, and questionnaires (Vol. 2). Rowman Altamira.

Smith, M. K. (2009). Issues in cultural tourism studies. Routledge.

Sugiyono. (2011). Metode Penelitian Kuantitatif, Kualitatif, $R \& D$ (GSukardi dan Gay (ed.)). Alfabeta.

Susanti, N., Latifa, I., \& Sunarsi, D. (2020). The Effects of Profitability, Leverage, and Liquidity on Financial Distress on Retail Companies Listed on Indonesian Stock Exchange. Jurnal Ilmiah Ilmu Administrasi Publik, 10(1), 45-52.

Vaismoradi, M., Turunen, H., \& Bondas, T. (2013). Content analysis and thematic analysis: Implications for conducting a qualitative descriptive study. Nursing \& Health Sciences, 15(3), 398-405.

Widagdyo, K. G. (2015). Analisis pasar pariwisata halal indonesia. Tauhidinomics, 1(1), 73-80.

Yang, L., Wall, G., \& Smith, S. L. J. (2008). Ethnic tourism development:: Chinese Government Perspectives. Annals of Tourism Research, 35(3), 751-771.

Yousaf, S., \& Xiucheng, F. (2018). Halal culinary and tourism marketing strategies on government websites: A preliminary analysis. Tourism Management, 68, 423-443. https://doi.org/https://doi.org/10.1016/j.tourman.2018.04.006

Zapata, M. J., Hall, C. M., Lindo, P., \& Vanderschaeghe, M. (2011). Can community-based tourism contribute to development and poverty alleviation? Lessons from Nicaragua. Current Issues in Tourism, 14(8), 725-749. 